\title{
Nation State, Political Identities and the Transformations of Globalization
}

\author{
Gabriel Pérez Pérez \\ Department of Social Sciences, Universidad Autónoma Metropolitana (UAM-Cuajimalpa), Mexico City, Mexico \\ Email: gpperez@correo.cua.uam.mx
}

How to cite this paper: Pérez, G.P. (2017) Nation State, Political Identities and the Transformations of Globalization. Open Journal of Social Sciences, 5, 9-30. https://doi.org/10.4236/jss.2017.54002

Received: February 4, 2017

Accepted: April 11, 2017

Published: April 14, 2017

Copyright $\odot 2017$ by author and Scientific Research Publishing Inc. This work is licensed under the Creative Commons Attribution International License (CC BY 4.0).

http://creativecommons.org/licenses/by/4.0/

\begin{abstract}
This paper explores and reflects the constitution of political identities and their relationship with the imaginary of power in democratic communities embedded in processes that have been called or known as dense globalization in the academic world. In this context, some of the major mutations suffered by the national state and the regionalisms that characterize today's global world, as well as the way in which political globalization affects the complexity with which political identities constructed, are examined. Finally, it is committed to the endeavour of the consolidation of democratic politics, understood as the form of government that has reached a larger consensus as a political regime, in a context of marked multiculturalism where the way in which communities of conscience and identity are built becomes crucial.
\end{abstract}

\section{Keywords}

Dense Globalization, Political Identities, Multiculturalism, Democratic

Consolidation, Minority Nationalisms

\section{Introduction}

The article is structured in three parts: the first is analyzed as a nation state which was established as a sovereign political system where sovereignty rests with the people; the political power of the nation state is in a territory where a certain type of nationalism is built. However, the model of nation state has been changing by the process of economic globalization from the seventies of the last century.

In this first part, we will see as the local-global dynamic has recomposed territorial spaces and affected in the references that build political identities, since a transfer of the power, has been given by the force of the global market and the strategies of multinational corporations, this process is known as "dense global- 
ization", characterized by a growing flow of networks ranging from the local to the global.

Globalization is affecting the political power sovereign of the nation state, deregulating controls power possessing opposite growing capitalist dynamics and the opening of markets. The globalization is a force transformative of all those fields social, institutional and structural, which has given a new process historical that affects those identities political. Nation state retains a good part of his sovereign power but have to negotiate part of his power to transnational and subnational institutions pushing for greater autonomy; this gives a new territoriality of political power, with losing centrality nation state.

The first part examines how there are two features that are essential to understanding the process of globalization and its effects in the field of politics and the resurgence of the importance of the regions: 1) there is a globalization of the economic system through the liberalization and integration of markets in the form of global production networks. As result there is a growing interconnection and interdependence between the different economies where is the national economy at a disadvantage against multinational corporations; 2) before the first is given a recomposition of spaces or the territorial principle, which generates a rearrangement of the various social conglomerates, which is political, demographic, and cultural as well as economic phenomenon. The global economy leaves little room for manoeuvre to traditional political mechanisms.

At the end of the first part of the article discusses the resurgence of minority nationalism, which is reactive to the exchange between the local and the global and the transformations that the national states are experiencing and large flows of migration to more affluent countries in search of better opportunities. Minority nationalisms are calling for the defense of their languages, cultures, religions and traditions. This represents a challenge to the nation state that seeks to maintain its homogeneity. In addition to the nation state and as part of globalization, it had been given regional integration processes seeking regional economic, cultural cooperation networks, and political.

In the second part of the article, we will see how is generating a new order global interconnected and dependent in many senses, primarily in the process of exchanges economic and financial, phenomenon that is generating both new forms of relations of power and authority, with their respective forms of hierarchy, inequality and exclusion. This affects the traditions of political decision of the nation state forms. It is in this context that the concept of "global politics" arises. This refers to the expansion of politics into a time and space framework that goes beyond the territorial state. The exercise of policy breaks with spaces barriers and upsets the traditional forms had been deployed as the power and authority that goes from the local to the global.

Global politics used the mass media to its expansion, its complex technological interaction networks that strengthen its effects, this causes impact on the global political processes because there is an extension of the actions and political decisions, which is structured in a local-global dynamic. In such a way, a lo- 
cal political event can have global effects and a global event have local effects.

The global politics breaks with the distinction traditional of political internal or external, which not indicates that the nation state let of be important, nothing more than now has that negotiate with many more actors and to a higher speed that in the last. These actors are of supranational, national, regional and local, which establishes a new dynamic of political life.

In the second part of the article stands out as political flows articulated in the form of complex networks of incidence have contributed to bring two items that reconfigure a democratic political culture: 1) they are generators of "radical democracy" to get to introduce fundamental issues of policy, for the solution of social problems that otherwise would be not taken into account and 2) are promoters of a global civil society and a cosmopolitan citizenship.

In the third part of the article is analyzes as the process of construction of it identity political, understood this as the universe symbolic associated to the exercise and them structures of power, that is refers to feelings, beliefs and values that give meaning to it political and that is established starting from the membership to a community, nation or ethnic, in an environment stable they are changing due to the process of globalization.

With the expansion of globalization it has transformed the political community and thus have altered the references that built political identity, particularly the impact of the media and the incessant flow of economic exchanges. The political community was forming from the growing centrality of political power, and the establishment of Governments in state structures. Nation state established a principle of territoriality and sovereignty in which political identity was built.

However, as we will see in the third part of the article, at present the political community has acquired a character of heterogeneity to interbreed with complex networks of power and decision-making processes. These communities are changing to incorporate into networks of regional and global integration of powers that scaled the traditional political spaces, globalisation sets new challenges for the new political communities.

In the debate over the relationship of the political community and democracy currently there are two fundamental positions, 1) critique of pluralist democracy in Mouffe position and 2) cosmopolitan Held proposal. The importance of these two proposed will be analyzed at the end of the third part of the article, so in them conclusion is makes a wide reflection to the respect and in relation to as starting from the ideal democratic is constitutes a community political, which is is each time more interconnected and related in multiple flat that is superimposed and that maintains an identity political that as citizens cosmopolitan have a consensus on them principles show as it claim of equality and freedom for all.

\section{The Nation State in the Face of the Trasformations of Globalization}

In the present paragraph is described them features of the nation state, for to 
understand which has been the impact that has had the process of globalization economic, particularly in the loss of sovereignty of the power political of the nation state, also as the dynamic local-global has recomposed them identities political and is has developed a transformation of them spaces territorial resurfacing with this them movements nationalist minority and them processes of integration regional.

The modern State is characterized by a political system separated from social activity, and by sovereignty held by a people and exercised by a "political class", generally elected and still professionally separated in an autonomous "political sphere". This people-system is installed as a set of legal-political institutions when a process of national fusion, articulated in various levels (economic or "market" unity, territorial unity, linguistic unity, cultural unity), is consolidated (Cerroni, 2000: p.18 [1]).

The modern nation state is a complex historical construct, which became a structure that expresses and condenses political power, and claims the legitimate monopoly of the use of violence for itself. It is comprised of a series of institutions and organizations that are deployed a in a clearly delimitated territory, and that require the construction of a particular nationality and nationalism, where sovereignty is materialized, and shared in a "world system of national states". It is also med of a "legal and political code", "condensing political and social relationships" in establishing de "space where the conflict takes place" in the struggle for political power.

Modern States became "units of political meaning" with representative faculties, separated from the sphere of civil society, constituting a "people-system" that articulates the concept of nation at different levels. However, the model of nation state that had been clearly established up until the end of World War II has now been disrupted by the process of economic globalization that has been developing, particularly from the decade of the nineteen seventies, and progressively taking momentum.

The local-global dynamics, the recomposing process of territorial spaces, the diversification of referents for the construction of identities, the intensification of progressive transferences of power-authority, the transformation of domestic-international behavior guidelines, are all being shaped by patterns generated by the global market and the strategies of multinational corporations. Current globalization shows differentiating and unprecedented features vis-à-vis its preceding versions. On account of these particular characteristics it has become what is being referred to as "dense globalization".

Globalization is directly influencing the limits and workings of the political power of nation states. This translates into larger economic openness that generates substantial challenges in the way commercial strategies and links are established, and a significant transformation of economic and social spaces. And also

${ }^{1}$ According to Held, et al. (2002 [2]), "dense globalization" can be understood as the current type of globalization which characteristic features are: high intensity and velocity, with a vast reach that affects the flows of increasing networks (local, national, regional, and worldwide), and with a tendency to affect all sectors of social life. 
because of the breakage and elimination of institutional frameworks that could hinder the functioning of "capitalism", from social and civil channels. This phenomenon is identified as a capital "deregulation process" at a planetary scale and it directly affects the degree of sovereignty and autonomy of national states themselves.

Globalization has been generating structural changes in the fundamental institutions of modernity; from industrial and labor organizations, types of governments, sovereignty international relations, and ways to face conflicts, to the intimate structures and strategies for the construction of personality, as well as of individual and social identities (Giddens, 2001: pp. 28-36 [3]). Globalization is an intense transformative force that drives fundamental and structural changes in the social, economic, political, cultural, ecologic, and military spheres. It is an unprecedented historical process that has come to disrupt the internal and external relations of current political societies in a major way. Therefore, we now speak of an increasing expansion of the political, social and economic space that determines the future of communities. However, it is a dynamic and open historical process, full of contradictions and paradoxes.

These are a series of processes that generate new forms of power relationships at global and local levels that, in turn, cause new stratifications and exclusion of vast social sectors. For Held et al. (2002 [2]), to talk about political North and South, First World and Third World, today, is to overlook the ways in which globalization has defined traditional inclusion and exclusion patterns among countries by forging new hierarchies across all societies and regions of the world. North and South, First World and Third World are no longer "out there", but they are intertwined within all major cities in the world.

Therefore, a process of deterritorialization of economic activity is in progress, which is propitiating the restructuring of national economies beyond their national territorial restrictions, along with processes of diversified reterritorialization. Although national states retain a fair share of their legal and political attributions within their territories, they have to compromise and negotiate many of their faculties with transnational and subnational entities and institutions who put pressure on them from different angles. In that sense, we face a transformation of the relations between sovereignty, territoriality, and the real power of national states, which has repercussions on what is known as a "new sovereignty regime".

The intensified global process not only shifts us from the traditional map of world geopolitics, but it also shatters the centrality that the state had occupied, as the actions of power are distributed among mobile actors that go from the local to the national, the regional, the macro-regional and the global. This in no way means the "end of the national state", but it suggests that significant adjustments and active refunctioning according to requirements are taking place ${ }^{2}$. There are

\footnotetext{
2“...the national state does not disappear; nations are rebuilt under the impact of the globalizing forces. In a sense, the national state has taken on more importance in the global era. We live in the first era in which the nation prevails as a universal form. In a way the global era is the peak of the nation state; however, it affects it as it changes its identity and trajectory. All nations of the world are rethinking their history, that is, they are reconstructing their identity within a globalized world, where the role played by nations is changes significantly" (Giddens, 2001: p.29 [3]).
} 
two characteristics that I see as fundamental to understanding the process of globalization and its effects on the sphere of politics, and the resurgence of the significance of regions:

1) Economic globalization, understood mostly in the sphere of finance and the way in which production and transnational interchanges take place, is generating substantial changes that directly influence the unequal treatment given to goods, capitals, and people. The existing aperture, intensification, and flexibilization have allowed to install a process of "mundialization of the economic system" through the liberalization and integration of markets in the form of "global production networks" (Held, 2005: p. 47 [4]). Thus, its components are undoubtedly the market and strategic forms of association that allow for an economic logic of instrumental functionality. It is a system with structures, agents, regularities, and relationships of power that comes about in the early years of the decade of the nineteen seventies; that is, when the necessary conditions for the establishment of new international finances were constituted, and it was possible for direct foreign investment to increase, for transnational enterprise groups to be strengthened, and for economic regions with intensified global repercussions to be established.

In this sense, there is growing interconnection and interdependence between different economies, wherein national economies find themselves in a disadvantaged position before the large amounts of capital generated by multinational corporations. This process depends on the backing and strength of every individual national economy, although the rules and forms for its functioning are being driven intensely by the economically strongest states and large multinationals. Nevertheless, the functioning of states remains fundamental for free market mechanisms, which constitutes a profound continuity in global environments. In the same process we can observe forms of internationalization and regionalization, where some countries with enough economic strength and big multinationals impose the rules of the "new economic game".

2) But this disruption of spatial recomposition, or recomposition of the "territorial principle" (Badie, 1997 [5]), generates a reallocation of the various social conglomerates, a phenomenon that is at the same time economic, political, demographic, and cultural. If we understand today's economy as the interweaving of a complex net in which highly dense flows, heterogeneous in their behavior, move generating processes of supraterritoriality, creating a significant shifting from the social and political coordinates linked to space and territory. Facing the increase in the intensity and the disrupting of spatial referents, the heterogeneous accelerated global economy leaves little leeway to traditional political mechanisms. Capitalist global economy constitutes fluctuating regimes for currency exchange, production and consumption, breaking away from the rigid referent of spatial territoriality, with the emergence of the "hypermarket" in the form of production regions and global networks. It is not that the new economy does not require spatial referents, but that it breaks away, reconstitutes, and refunctionalizes them; thus, we can see how the flows of the heterogeneous economic net- 
work go across and creatively take advantage from local, national, and regional spaces, reproducing incessantly (Martínez, 2002, [6] and Held \& McGrew, 2003 [7]).

What has been called the "crisis of the territorial principle", understood as the questioning of the process of the modern political arrangement, that spans from the end of feudal society to the Treaty of Versailles, right through the Westphalian agreements, has to be interpreted-as pointed out by Badie (1997 [5]), and in a way by George (1995 [8]) as well-not as the abolition of spaces but as their proliferation and flexibilization as products of the globalization process, significantly affecting the arrangement upon which international equilibrium and legitimate political authority rest to a great extent.

The current global environment causes several spatial logics to coincide, which in various ways cut through local territorial references of national states currently in under a phase of transformation. This "mutation" of the world geopolitics and basic territorial referents is the product of the intensification of the process of economic globalization and of the proliferation of multiculturalism. But also of the mobilization of individuals due to great migrations, the telecommunications and world transport revolution, the multiplication of particularisms and ethnic and cultural expressions of different origins. Territoriality ceases to be the exclusive support of legitimate political power and becomes just one more referent.

The transformation of territorial spaces generated by economic globalization has direct repercussions in the social configuration of the various political communities and their right to self-determination. And along these disruptions, from the decade of the nineteen sixties we see the resurgence of social and political phenomena that have grown in strength and impact over a little more than three decades: an "ethnic revival" (which would include demands from immigrant groups, vindication movements of indigenous people, and national minorities facing a process of clash and intensification) (Kymlicka, 1996: pp. 26-30 [9]), the reactivation of the so called "new social movements", transnational defense networks, and the surge of citizenship.

Regarding the resurgence of minority nationalisms, that are reactivated by the dialectic interchange that the flows of capital have generated between the local and the global. But also, by the transformation that plurinational states are experiencing and the great flows of migration toward more prosperous countries in search of better opportunities; thus, national states find themselves facing pressures from multiple flanks: supranational, because of the pressure and exchange generated by global capitals, the great transnationals, the pressures imposed from regional economic niches and other national states demanding economic cooperation and commercial exchange; national, because of the various frictions that national power relationships have generated, and subnational, because of the different national and ethnic minorities seeking adjustment and autonomy within a larger host state.

Thus, the emergence of national ethnic-cultural minorities, such as those in 
Quebec, Flanders, Catalonia, the Basque Country or the Ulster region, just to name some of the most significant examples, and the vindication of their autonomy, are benefited by the new context of the global economy and economic regionalization; even though the growing interconnection and interdependence of economies around the world, and the complexities generated by intense competition, leave little room for the possibility of actual independent secession of these entities, international pressures assert that these national minorities have full rights to defend their languages, cultures, religions, and traditions. Without a doubt, this is a challenge for national states, seeking to retain their traditional style homogeneity at all costs ${ }^{3}$.

Additionally, and as part of the same phenomenon of resurging regions facing the nation state, as rightly pointed out by Keating (1997 [10]), we find ourselves before a new regionalism. There is a new wave of regionalism that presents itself strongly at the end of the nineteen eighties, not only within states but, for example, in the context of the European Union and the global market. Most European states have decentralized their institutions in order to update themselves and rationalize management and administration, and in many cases as a means to strengthen state autonomy. In the case of European integration, regional development funds, which have increased notably, have placed regions in a more direct relationship with the EU, weakening mediation by central authorities even if the latter remain the main actors. In Ireland, for example, competition over these funds has led to the establishment of regional structures that may qualify to obtain them, while in other countries the need to strengthen regional institutions or to reconfigure regional limits for the competition with Europe at large has started to be discussed.

There is a great variety of forms of regional administration. In the United Kingdom there is a deconcentrated administration by the central State, in the cases of Scotland, Wales, and Northern Ireland, which are part of the central government and headed by national ministers. A functional form of regional administration, based on the functional needs of the central state, rather than on a political drive from the bottom, is also identified. In this sense, we can observe the existence of regional agencies that manage to get control based on loopholes in the legislation, which makes these regions a sort of "no man's land" in constitutional terms, just like in the case of England. The regional federalist government such as that of Austria, Belgium, Germany, or Switzerland is the strongest among the various forms of regional government. Also distinctive is the case of Spain, with a government of strong regionalisms, or those of Italy or France, where an asymmetric regionalization can be seen, and much weaker regions with limited competence and autonomy can be found, while regions in key situations

${ }^{3}$ It is interesting to highlight how some National Movements within the globalization process (such as the cases of Quebec and Catalonia) link their political struggle for more self-determination or autonomy to the economic development of their region. That is to say, part of the justification by the nationalist movement to obtain autonomy or even independence from the national state is that it would mean economic success for the collective of citizens who live in the region, which gives the movement a utilitarian and pragmatic sense. 
are given special concessions (Keating, 1997 [10]).

\section{The Configuration of Global Politics}

Globalization is the convergence of dynamic and heterogeneous processes (measured by their reach, intensity, velocity, and repercussion) that are severely transforming spatial and temporal organizations of social relations by generating trans-territorial flows and networks that directly affect the functioning of current authority and power. This last characteristic is what I am particularly interested in discussing here. A new global order is being generated, interconnected and dependent in many ways, fundamentally in the process of economic and financial exchanges, a phenomenon that is, in turn, generating new forms of relationships of power and authority, with their corresponding forms of hierarchy, inequality and exclusion.

This process not only affects the functioning of the national state and the traditional procedures for political decision significantly, but also the very nature of politics and modern political communities. Thus, the concept of "global politics" refers to the expansion of politics into a time and space beyond the territorial national state 4 . It is a broad exercise of diversified politics that breaks decidedly with its geographic-spatial restrictions and disrupts the traditional forms in which power and authority had been deployed. It is also a form of disruption that influences the local, regional, macro-regional and world levels. Some of its characteristics can be pointed out as follows:

(a) It refers to a broadening and expansion of politics, since certain political actions or decisions that are carried out in a given place, because of the characteristics of interconnection and interdependence mentioned above, immediately branch out to many parts of the world. It is a phenomenon of differed repercussions at multiple levels.

(b) We speak of a rapid communicative linkage of political decisions and actions, via complex networks developed by the technological revolution of satellite telecommunications and the intensification of transport routes. It is through these accelerated and drastic technological transformations that global politics can be expanded to a great extent. It is a phenomenon of technification of global politics.

(c) Because of the former conditions that cause global political processes to have profound repercussions (stretch and instantaneity of political actions and decisions) a global-local dialectics is structured. In this way, developments at the global level have a direct impact at the local level, and developments at the local level have direct impacts at the global level. It is a phenomenon of approxima-

\footnotetext{
$\overline{44 . . .}$ "global politics" ... [is] the ever larger expansion of political networks, of interaction and activity in the political environment. Decisions and political action in some part of the world can rapidly branch out at a world scale. The centers for political action and/or decision making can quickly link through fast communications over complex networks for political interaction. Along with this "stretching" of politics is the intensification or enhancement of global processes to the point that the "remote action" penetrates the social conditions and cognitive worlds of places of specific places". (Held and McGrew, 2003: p. 29 [7]).
} 
tion and redimensionalization of spatial borders.

It is the breakage of what has been called, not without certain irony, "official politics" or "symbolic politics", what will allow the emergence of other forms of political manifestation (Beck, 1999 [11]). Indeed, the notion of global politics renders the traditional distinctions between internal and external politics, and so on, dysfunctional. However, this process of extension and diversification of politics must not be confused with a loss of relevance by national states, nor does it signal their inevitable extinction, as it was once asserted insistently. Governments and nation-states still play decisive roles in world geopolitics, they become powerful actors who have to share and negotiate with several international and intra-national organizations, bodies and actors, in a new complex environment of politics.

We can argue that actions and decisions by national states are impelled both from a supranational or transnational level, as well as from the regional, in tra-national, and local levels in their multiple projections and ramifications with worldwide repercussions. The very solution to their apparently domestic problems has to consider and integrate the different levels of influence of the exercise of global politics. The power being exercised from the various spheres of the global constitutes a necessary referent to understanding the "changing constellation of political life" (Held, et al., 2002: p. 25 [2]).

This exercise of politics and global power is becoming what has been called "international regime". This regime is formed from the constant interaction between the exercise of power and the economic structures upon which it works. It is, of course, a differentiated and asymmetric use that results in deregulated practices that generate "distinctive regimes". Precisely this actual asymmetry evidences the need to search for regulation and cooperation mechanisms that seek collective solutions to erratic problems and the evasion of responsibility.

It is the complex scenario of interaction between several political actors, with a variety of interests that range from intergovernmental to transnational, including those strictly governmental. It responds to the demand for the reproduction of global capitalism that attempts to influence various spaces generating relations and linkages at a world level, by restructuring pre-existing social links and unequal economic maneuvers, causing a reconfiguration of political power that seeks to influence on multiple spheres and levels through the ramification of interactions.

It is within the mobile framework of international regimes where the exercise of power and authority is established in a scenario that lacks unique bodies and institutions that are able to minimally govern the process. Therefore, in the age of the "postnational constellation" (Habermas, 2000 [12]) global politics, the exercise of power-authority, and the new international regimes drastically disrupt the very nature of politics, the decision making mechanisms, and the national, regional and global functions and institutions.

This internationalization element of politics and social relationships comes fundamentally from the internationalization of power, since "there has been a 
marked extension of the network infrastructures and institutions, the establishment of rules and global political activity" (Held, et al., 2002: p. 35 [2]). This could represent a transit from a political regime centered on interstate or territorial geopolitical relations to trans-territorial regimes of global power that break with the traditional referents and coordinates of politics.

Global politics is transforming the foundations of the local, national, regional and world order. However, it is necessary to keep in mind that it is an open and contingent historical process. What is important is that it places national states inside of dense spatial networks of different dimensions that modify their functions in a complex constellation of global power; this is expressed in a plurality of overlapped and contradictory political processes that involve multiple actors and levels of functioning.

The former division between national and international politics is fading, a process that is ongoing since the nineteen seventies. The diversification and broadening of politics toward multiple levels of influence, by means of varied resources and participating with multiple agents, makes it possible to observe the configuration of current international networks, where both "new minority nationalisms" and "transnational defense activists" settle, interact, and generate flows of different importance. Thus, we could start to speak about "a politics that is no longer regulated, but that modifies the rules, that is... a politics of politics (or metapolitics)" (Beck, 1998: p. 100 [13]).

It can be argued that these political flows, articulated in the form of complex networks of influence, contribute two closely linked fundamental elements, that without a doubt influence the re-configuration of a democratic political culture: i) they are generators of "radical democracy", as they manage to reinsert, into national and international political agendas, topics that are fundamentally relevant in public policy, in the solution of fundamental social issues, that would otherwise be absent due to the increasing withdrawal of the social commitment of the national state, and ii) they become promotors of the urgent need to build a "global civil society" and a "cosmopolitan citizenship"5.

Attempting to measure the modifications that the national state is being subjected to presupposes acknowledging a complex historical and political formation that we need to revise in order to cautiously gauge their multiple repercus-

\footnotetext{
${ }^{5}$ It would be important to insist that it is globalization and economic deregulation which precisely make the emergence of new actors and powers possible, as these actors flexibilize and go beyond the rigid state structures and their principles of territoriality, sovereignty, and legitimacy, via the use of the notable advances in telecommunication technology. For a more punctual analysis of those strategies see Ibarra, Martí \& Goma (2002 [14]). Regarding the proposals of cosmopolitan citizenship see mainly Habermas (2000 [12]); Held, et al., (2002 [2]), and Fistetti (2004 [15]). Regarding the project of a cosmopolitan or "postnational citizenship», we cannot forget the difficulties it holds as it is linked to matters such as sovereignty and power, typical of modern democracy; if we consider that this mega-citizen must exist in a postnational political community (say, for instance, the EU) it breaks away completely with the traditional notion of politics that regarded the national state as the ultimate and insurmountable repository of popular sovereignty, how to prevent the problems of the national state, such as the excessive concentration of power, the waves of mass migration, the protection of fundamental rights, the struggle against poverty, racism, corruption, or the provision of security, only to name a few, to be reproduced in an amplified form?
} 
sions. The political genesis of the state dates back from the mid fifteenth century. Its main driving force will be the emergence and exercise, in the face of the birth of a sort of world-economy, of an autonomous and secular power that would later, during the nineteenth and twentieth centuries, become a sovereign territorial national state. It constitutes itself as an omnipresent entity in the social life of peoples and the mechanism for the regulation of the total existence of man.

This feat will only be achieved through a sort of arrangement woven from various elements (legitimacy of state power, a body of laws, cultural and linguistic common bonds...) that makes ultimately possible "the unicity of political power projected territorially on the social layers that lend the state a human element, along with the cultural homogeneity that the state itself will update, and gives way to that ideology called statism, as a vocation asserted on the permanent attribute of state power as the only power" (De Blas, et al., 1999 [16]).

It is mainly after 1945, with the destructive and traumatic elements left by World War II, that the development of the social democratic state as a western model "exportable to any part of the globe" will be possible. The construction and development of the social state at the national level made it possible to limit an uncontainable and savage capitalism, but it also allowed, with all the deficiencies that can be pointed out, the development of a state with a social calling for the establishment of modern democracy.

The functions that states had been fulfilling are precisely that which is involved in an accelerated process of transformation and refunctioning. But this should not be seen as something merely negative; now that the notion of the "end of the state" seems to have been abandoned, and in the face of the contradictions and insufficiency displayed by the liberal-democrat model-adjusted up to its limits-(De Blas, 1995 [17]), it is time to consider the serious need for a fundamental and decisive transformation that allows the (re)functioning of a state that is fully adapted to the problems and challenges that the new global times pose. The debate over this is intense, heated, and contradictory; however, in my estimation, it would be better understood as the extension, intensification, enhancement and legal institutionalization of many of the proposals and practices currently being put forth by these heterogeneous collective political actors, than from local concerns trying to influence global environments and vice versa.

\section{Identity, Plurality and Political Communities: A Bet on Democratic Politics}

The process of "identity" construction has become a fundamental issue for the understanding of the complex dynamics of current societies: "it can be argued that "identity" has now become a prism through which all other aspects of interest in contemporary life are discovered, understood, and examined. The questions established from the social analysis are being referred and renovated in order to adjust to the discourse that now revolves around the axis of "identity" (Bauman, 2001: p. 161 [18]). However, the very question of the construction of identities has become so complex because of the plurality of paths and aspects 
that can intervene for their formation. Traditionally, identities had been established from the main references of belonging to a territorial community, nation, or ethnicity ${ }^{6}$.

It was generally established from the convergence of those elements in a more or less stable environment that allowed their continuity without many difficulties. Now those referents have been drastically disrupted with the increasing expansion of globalization, the influence of communication media, the incessant flows of economic exchanges, and massive emigration processes. Besides, the forms of socialization are not being woven through the mediation of universal referents. Therefore, we can now speak of our "complex identity" (Taylor, 1996: p. $15[20])$.

Just like individual identity is formed within a given community, a political identity is constituted from belonging to a political community (Fistetti, 2004 [15]). The political community had been formed from the growing centrality of political power, the establishment of governments upon statal structures, the configuration of territorial boundaries and responsibilities for the exercise of politics, the articulation of an interstate order. This development stemmed from the consolidation in the West, during the seventeenth century, of the "society of states", where the territorial and sovereignty principles where the main structuring elements of that order.

The territorial principle was able to establish those delimitations that allowed distinctions between belonging in one given state and another. However, the not so clear geographic coordinates will be stabilized only during the nineteenth and twentieth centuries. The sovereignty principle conferred the right to govern within the previously determined territory. And the autonomy of the states spoke of the real power they had to determine and articulate particular political goals independently from other state configurations. These entities managed to sufficiently integrate the specific characteristics of a "people" within the territory configured by a national state.

The political community thus constituted a "national community of destiny" that retained cultural identity features as a territorially settled people. It is pertinent to clarify in this point, that the connotation of people assumed here is freighted with political construction; therefore, we have to distinguish between, on the one hand, "(im)possible people" with a markedly idealized character, and on the other, "real people", whose characterization is mostly related to political action, as an exercise for its configuration as a political society in the public sphere.

Understood in such a way, the political community constituted the propitious space for the development of citizenship and democratic politics. This development will be achieved mainly through democratic liberalism, harshly criticized

\footnotetext{
${ }^{6}$ According to A. Melucci, collective identities realize three basic intimately implicated functions: (a) they generate cognitive frameworks that give sense to the actions performed; (b) they establish relations between the constituent members that interact, communicate, and make decisions, and (c) they establish emotional inversions that allow the reciprocal recognition among those implicated (Letamendía, 1997: p.91 [19]).
} 
nowadays and many of its governing tenets being strongly questioned. We should recognize, nonetheless, that it has become one of the fundamental pillars for the development of modern democracy and contemporary political thought. The great debate around it is proof of this assertion.

What we recognize as political communities has acquired a heterogeneous character by intertwining with complex power networks and decision making processes. Political communities are evolving as they become inserted in networks of regional and global interaction of powers that reconfigure traditional political spaces; effective power has to be shared and constantly negotiated with other agents and international entities. This, as I have asserted, speaks of a transformation of national sovereignty and a reconfiguration of modern political power. Globalization becomes a contingent process loaded with multiple challenges for new political communities.

There are several levels to the debate on the political community and modern democracy. Let us consider two fundamental stances: (a) the critique of pluralist democracy from the view of Mouffe (1999 [21]), and (b) the cosmopolitan proposal of Held, et al. (2002 [2]). These are two referents necessary for the debate on the crisis of democratic liberalism and the increasing implementation of an economic globalization that disrupts the referential scenario for the political community and democracy.

(a) Mouffe (1999 [21]) starts from the question of how to establish the political community and citizenship within the framework of a community that is compatible with liberalism. Firstly, she highlights the need of a political community for the development of democracy, but what kind of community is this? Of course, she is talking a "democratic political community", but how is this constructed?

In the first place, politics is established as the determining element for the construction of a political community. It becomes the place where multiple interests, demands, and intentions converge, which in order to cohere requires the identification of a notion of a "we", therefore becoming a mechanism for inclusion and exclusion simultaneously; inclusion, because it would allow the integration of its constitutive members based on different elements (cultures, language, tradition, religion, and so on) but above all on the search for "common good" (as a "framework of political meaning" or "political perspective"), and exclusion, because by constituting itself as a "we" it has to be differentiated from the "others" who do not belong, thus marking the boundary of what makes the community.

But in order for it to become a proper democratic and pluralist political community it is necessary to it be structured, not on the substantial idea of the "common good", whatever this may be understood to be, but upon a "consensus on the ethical-political principles of the democratic regime: the affirmation of freedom and equality for everyone" (Mouffe, 1997: p. 41 [22]). But as this "ethical-political consensus" is realized, all those who do not fully take it on result being excluded, and this very exclusion and inclusion mechanism of the con- 
sensus makes its full realization impossible.

The democratic consensus is an im-perfect process, but is always perfectible, open, and contingent. It is, therefore, a political community always in motion, but constantly regulated by the democratic ideal. The political community constitutes a "political identity" as citizen subjects belonging to that community. It is in this political identity, as a formative structuring based on the full assumption of the consensus, that simultaneous belonging to other communities with marked differences is achieved.

The political community becomes a sort of artificially constructed community for the participative exercise of political action. It tries to structure a mechanism that is sufficient for the acceptance of freedom and pluralism of each and every one of its members. And it is through this simultaneity of levels of belonging that a "community of respect" for the subsistence of multiple cultures of differentiation can be achieved. Given that one can belong to and identify with several cultural manifestations that can coexist and reconcile in the exercise of belonging to a democratic political community, it can become the linchpin for the coexistence of multiple cultures of differentiation and various forms of identity construction.

According to Mouffe (1999 [21]), because of its structural characteristics, this type of community does not have a defined form, since it is constantly under a process of redefinition. The fundamental issue is the acceptance of all actors within it as free and equal persons, regardless of the multiple forms of identification and cultural belonging that are expressed in that space, as long as it takes place in an open environment of democratic politics. This construct of course responds to a type of democratic citizen that is drawn from the main reference values, namely freedom and equality.

Now, the democratic consensus put in place in the political community by its forming citizens, through the exercise of democratic politics, sets a new distinction between the "friend" and "enemy" relations for the understanding of politics set forth by Carl Schmitt. Since the aim of pluralist or radical democracy is to pursue the establishment of a mechanism that is able to install a consensus of democratic politics within the framework of freedom and diversity, this consensus must not be crushing. In contrast, it should allow dissent as an expressive characteristic of the development of freedom and pluralism.

Therefore, Mouffe (1999 [21]) proposes the development of an "agonistic pluralism" as a democratic element, since in the full acceptance of the established rules in the accepted consensus-a consensus that means the acceptance of the basic rules of pluralist democracy-the multiplicity of interpretations that occur within the political community become a battle between "adversaries", whose acceptance within the consensus is openly recognized. The relationship with the "enemy" of the classic distinction would only apply to those that did not accept the consensus and keep outside it, devoid of the possibility to deliberate freely within a minimal framework of democratic acceptance. The establishment of a "democratic political space" within belonging to a "political community", 
which defines a "political identity" that is susceptible of being deployed in the form of the democratic practice of citizenship, is the way to achieve a sufficient level of homogeneity that can subsist in the midst of the diversity and conflict that make up its own identity as a political community.

(b) The proposal by Held et al. (2002 [2]) is aimed at measuring the limitations and possibilities of the political community and democracy in the new context of broadening of the world economy and the international society. It sets off from acknowledging that all the transformations driven by globalization no longer make it possible for us to consider "political communities" and "political civilizations" separately.

Political communities are increasingly interconnected and implicated in multiple relations and superimposed levels. This type of complex approximations maintain inequality, hierarchy, and exclusion relations constant, which we ought to bear in mind, but the dialectic process between the global and the local has repercussions even over those states considered stronger and more solid. Held et al., (2002 [2]) outline five points that show the way in which political globalization is transforming national states, but also allow to measure the evolution process to which "democratic political communities" are subjected to.

1) Political power has ceased to reside in national governments alone, since the emergence of various local, national, regional, macro-regional and global actors and powers makes it more complex. Therefore, political power has to be shared, negotiated, and exchanged between the different agencies interacting at the different levels of influence ${ }^{7}$.

2) Because of the opposing effects, the structure of a "political community of destiny" cannot be located within the now reduced coordinates of territorial national states. The very composition and fate of the political community stretches beyond the parameters of national limitations, in order to insert itself in the "world political system".

3) The compelling action of national states in the context of the global economy constantly questions the autonomy and sovereignty of the traditionally configured state system. "While massive centralization of power is still characteristic of many states, they are often inserted in fragmented domains of political authority and articulated with them".

4) The emergence of multiple border problems that are radicalized with the process of mundialization. The coexistence of various political communities is

\footnotetext{
${ }^{7}$ Put another way, inside modern liberal democracies there are several aporias that are hard to resolve: (a) between freedom and security; (b) between universalism and contextualism (or individualism and community); and (c) between politics and power. This last one refers to the disparity, and certain opposition, produced between politics (still too fixed to the local and the national) and power-authority (extraterritorial) as capitals and finances turn nomadic and break away with any sort of border, they affect the politics "concerning the vital sphere of decisions, they are still locked in the space of national states. Here we observe, once again, the emptying and dissolution of the modern category of sovereignty, since it stops working as a project of inclusive universalism and, instead, produces those without community, those without rights, without work, without homeland, without documents, that is to say, a human or infrahuman figure, that is left aside and is, therefore, expendable, just like the homo sacer of roman law... it produces an increase of insecurity and a multiplication of risks" (Fistetti, 2004: p. 169 [15]).
} 
increased and strengthened through multiple ways that overlap shared destinies, which they have called "overlapped communities of destiny", generating different problems with partial and imprecise solutions. This refers to problems such as: massive migrations, labor, ecologic, security and other issues. "In a world in which powerful states make decisions not only for their own people, but also for others, and where transnational forces and actors cross the borders of national communities in different ways, the aspects regarding who should accountable before who and on what basis are not easily sorted by them".

5) Another aspect corresponds to the lack of precise delimitation between domestic and foreign affairs, interior policy and international policy, state concerns and extra-state issues. It is no longer feasible to face problems such as drug addiction, delinquency, AIDS or SARS, environmental risks, and so on, from the reduced framework of local governments. In order to resist the multiple risks that political communities face it is essential to start thinking about them from a new world problem and risk sharing logic, and also to propose possible solutions in a register of multilevel interaction and cooperation.

\section{Conclusions}

We have seen how economic globalization has impacted on the sovereign capabilities of the nation state. There is a deregulation of the controls the nation states had facing the growing capitalist dynamic and the aperture of markets. This has not meant the disappearance of the nation state, but if it has decreased its hegemonic power with other actors such as transnational corporations. We have seen how economic globalization has impacted on the sovereign capabilities of the nation state. There is a deregulation of the controls; the nation states had facing the growing capitalist dynamic and the aperture of markets.

With these changes, it has emerged what we called "global politics" which refers to the extension of the policy in a time and space beyond the traditional scope of the nation state that goes from the local to the global, in such a way that a local political event can have a global impact and vice versa, as well as change the processes of political decision-making. I have emphasized how all these changes have affected the configuration of political identities, starting with how political communities are currently being constituted. Facing these events, an opportunity opens for the development of democracy, as I will highlight in this conclusions.

The convergence of several changes in many levels of our social, economic, and political life is undoubtedly generating an intense regional and global interconnection that is necessary to consider in order to mediate the transformations in spheres such as the political community and democratic politics. Such structural changes are influencing: i) current human rights regimes, ii) the internationalization of security, iii) the transnationalization of countless defense programs, iv) severe environmental changes, v) a revolution of telecommunications and information technology. These aspects certainly disrupt the nature and composition of contemporary political communities and the construction of identi- 
ties in a direct way.

The political space where governments traditionally operated and where the public responsibility of their political power was delimitated can no longer be conceived of only within the narrow limits of national territoriality. Therefore, it is indispensable to expand the conception of a political community of destiny toward the configuration of a "community of overlapped destiny" that responds to the increasing linking and interconnectedness between individual political communities. But this becomes a major problem to resolve the dilemmas that modern democracy faces these days ${ }^{8}$.

This is related to the "quality of democracy" in the current type of societies, with social communities in transformation processes and a marked democratic deficit, and a transnational power that intervenes in the various interconnected and overlapped levels. In the context of the national state, the quality of democracy is understood as the effective practice of citizens in the making of political decisions as part of a process of responsible control within a given political community. But this quality does not stop at the deliberative process and the making of public decisions through suffrage. It is necessary to acknowledge that the quality of democracy "depends on the complex processes through which citizens achieve access to the resources and procedures of the public sphere or not, an access that reflects a complex pattern of economic factors, cultural processes, and social participation". But in today's conditions, what is the meaning of democracy and citizenship in the complex societies of globalization? The following are some proposals:

1. The people have to govern through international communities, associations, states and organizations, all of them under cosmopolitan democratic law.

2. The way of exercising global power is the "heterarchy", as a type of divided authority, under democratic cosmopolitan law.

3. The key agents and instruments are constitutional and institutional reconstruction, intensification of globalization and regionalization, new social movements, imminent global crises.

4. It is inserted in the tradition of liberal democratic theory, pluralism and democracy of development, democracy of participation, civic republicanism.

5. The ethics of the exercise of global power subscribes to "democratic autonomy".

6. The process of transformation of politics is the reconstruction of the global exercise of power (Held, et al., 2002: pp. 554-565 [2] and Held \& McGrew, 2003, pp. 137-156 [7]).

Regarding the exercise of citizenship, it will have to stretch from the sphere of the local, to that of the national, and the global. Political subjects need to learn how to be "cosmopolitan citizens", as they are constituted as people capable of transiting and mediate between communities of destiny, the national framework, ${ }^{8}$ As a starting point, let us say that a loss of power and authority has produced; since there can in no way be an automatic and mechanical transfer from the state to other actors who form a sort of "world community", as a good amount of that authority is being lost gradually, resulting in a society in the hands of a non-government (ungovernance) (Fistetti, 2004: pp. 166-170 [15]). 
and various alternative ways of life. The mediating role of citizens in complex democratic political organizations will be linked to broad exercises that can link "dialog with tradition", the diverse discourses of other cultures of differentiation with the intention to increase the "spheres of action of mutual understanding".

Thus, political actors diversify, and intensify their influence in multiple overlapping levels of the complex configuration of the "postnational constellation". But the change in political actors as "world citizens" has to be complemented with significant transformations of our most important democratic political institutions; otherwise we will not be able to face the challenges posed by economic globalization. It can be argued that even though the "national states system" is still in place, nationalism and conflicts between national states are growing; its functions are thus re-signified. We see an economic system that constantly erodes territorialities and societies enclosed by static national borders; the autonomy and sovereignty seem to lose consistency before the international practices of global politics.

International capital, of course, does still require determinations from territorial national states (security, negotiation, implementation...) in order to articulate its requirements and needs. Globalization is not a-statal, but trans-statal, therefore, state determinations are subordinated to economic pressures, also implemented by better consolidated and stronger national states. There is talk of a "new institutional design" that generates a new more efficient state that does away with tasks that do not pertain to its structuring functions of "balanced negotiations of interests".

We can say that sensitive modifications in the sphere of space, territorial sovereignty, and autonomy, as determining characteristics of modern sates, are undergoing a process of functional "renegotiation" in a changing dynamic of the dialectics between the global and the local, Robertson's (1992 [23]) “glocalization". As we have observed, modern states are formed by multiple complex and overlapped levels that are constantly tensed by putting autonomy, sovereignty, and territoriality to the test in a new scenario that breaks away from the old referents and coordinates needed to understand features such as the exercise of "political authority" or "international relations".

Although the construction that led to the fragile consolidation of modern states-which spans from the Peace of Westphalia (1648), through the WWII postwar (1945), to the end of the Cold War (1989) — is in question today, what this shows is the lack of definition and permanence of a process that today is fully open and full of uncertainties.

If we understand the process of democratization of current societies as the structuring from which the progressive extension of citizen participation in the decision making of states on social development issues, with the globalization process and its direct impact on the regulatory role of the state, political actors and democracy itself become problematized. That is, if the state minimizes its functions and if the spectrum for state decision is reduced and restricted, the national and local context as a formation of identity, will, and decision is severely 
affected; thus, the referential categories of "political belonging" and "citizenship" are significantly limited and disrupted.

With this intense inversion of modern geopolitics generated by the spatial and economic restructuring processes of globalization, which is deeply modifying the foundations of the world order itself; the territorial sovereignty of national states, the configuration and functioning of political communities, the forms of democratic-liberal politics. The amplification and diversification of political spaces is a product of "global politics", ever more complex due to the acceleration of flows of movement taking place through multiple levels of the world network.

These changes have direct repercussions in the composition of the relations of power, figures of political authority, control mechanisms, regulation, and political decision making. In this way, the "new political (dis)order" must be understood as a "highly complex, interconnected, and disputed" system, where the various political actors (national states, minority nationalisms, international defense networks, diverse multinational organisms, and great transnational corporations) are intertwined and dispute privileged spaces of power at multiple levels, generating what has been called "regional and global governance".

It is clear that globalization is not a monolithic, unitary, and static process, but in fact the opposite, within the innumerable fissures and contradictions that characterize it, at the same time, it makes diversified political practices possible, of which current political communities are taking advantage in their own ways. In this regard, the diversified and flexible strategies that New National Movements are generating as they negotiate and continually broaden their leeway for action, by putting pressure on the host plurinational states and becoming political agenda setters and generators of spaces to produce public policies, are particularly significant. Thus, in the current global environments the levels of mobility and resonance are amplified as they become important political actors working in the broadening of a more democratic vision of global governance and pushing for structures of political opportunity. They become political forces-with very concrete and specific interests-that, from various fronts, strategies, and resources, attempt to include topics such as human rights of minority groups, policies of recognition, self-government and autonomy rights, the search for more equity in the distribution of resources, concerns for the environment, protection of fundamental liberties, sustainable development, extension of pacific relationships; in short, the promotion of global democracy and social justice.

Finally, what I wish to emphasize here is that in this complex environment of globalization and global politics, multinational states are being pressured, and at times surpassed, from intrastate spaces, by minority regional nationalisms that fundamentally seek their recognition and democratic accommodation within these states via cultural proposals of autonomy and the institutional-legal pursue of self-determination mechanisms. The theoretical proposals of federalism and nationalism need to reconsider many of their basic tenets and political mechanisms of articulation, so that they can creatively adapt to the new global environ- 
ments. Otherwise, dangers such as secession, systematic violation of rights of minorities, or democratic deficit will be impossible to tackle and dissolve adequately in today's societies. Let us start by revising the main problems and paradoxes that national cultures and minority nationalisms are experiencing, for which we will need to dig deep into the intense and disorganized contemporary nationalist debate.

\section{References}

[1] Cerroni, U. (2000) Política. Método, teoría, procesos, sujetos, instituciones y categorías. Siglo XXI, México.

[2] Held, D., et al. (2002) Transformaciones globales. Política, economía y cultura. Oxford University Press, México.

[3] Giddens, A. (2001) Lecciones globales. Nexos, 287, 28-36.

[4] Held, D. (2005) Un Pacto Global. La Alternativa Socialdemócrata al Consenso de Washington. Taurus, Madrid.

[5] Badie, B. (1997) La Fin des Territories. Essai Sur Désordre International et Sur I'Utilité Sociale du Respect. Éditions Fayard, Paris.

[6] Martínez, Á. (2002) Globalización y recomposición de los espacios económicos nacionales. El margen de maniobra de las economías en entornos globales. In: Palazuelos, E. and Vara, M.J., Eds., Grandes áreas de la economía mundial, Ariel, Barcelona, 25-63.

[7] Held, D. and McGrew, A. (2003) Globalización/Antiglobalización. Sobre la Reconstrucción del Orden Global. Paidós, Barcelona.

[8] George, P. (1995) Geopolítica de las Minorías. Oikos-Tau, Barcelona.

[9] Kimlicka, W. (1996) Federalismo, Nacionalismo y Multiculturalismo. Revista Internacional de Filosofía Política, 7, 20-54.

[10] Keating, M. (1997) The Invention of Regions: Political Restructuring and Territorial Government in Western Europe. Enviroment and Planning C: Politics and Space, 15, 383-398. https://doi.org/10.1068/c150383

[11] Beck, U. (1999) La invención de lo Político. Fondo de Cultura Económica, Buenos Aires.

[12] Habermas, J. (2000) La Constelación Posnacional Ensayos Políticos. Paidós, Barcelona.

[13] Beck, U. (1998) ¿Qué es la globalización? Paidós, Barcelona.

[14] Ibarra, P., Martí, S. and Goma, R. (2002) Creadores de democracia radical. Movimientos sociales y redes de políticas públicas. Icaria, Barcelona.

[15] Fistetti, F. (2004) Comunidad. Ediciones Nueva Visión, Buenos Aires.

[16] De Blas, A., et al. (1999) Enciclopedia del nacionalismo. Tecnos, Madrid.

[17] De Blas, A. (1995) Nacionalismo y naciones en Europa. Alianza Editorial, Madrid.

[18] Bauman, Z. (2001) En busca de la política. Fondo de Cultura Económica, Buenos Aires.

[19] Letamendía, F. (1997) Juego de espejos. Conflictos nacionales centro-periferia. Trotta, Madrid.

[20] Taylor, C. (1996) Identidad y reconocimiento. Revista Internacional de Filosofía Política, 7, 10-19.

[21] Mouffe, C. (1999) El retorno de lo político. Paidós, Barcelona. 
[22] Mouffe, C. (1997) Liberalismo, pluralismo y ciudadanía democrática. Instituto Federal Electoral, México.

[23] Robertson, R. (1992) Globalization: Social Theory and Global Culture. Sage, London.

Submit or recommend next manuscript to SCIRP and we will provide best service for you:

Accepting pre-submission inquiries through Email, Facebook, LinkedIn, Twitter, etc. A wide selection of journals (inclusive of 9 subjects, more than 200 journals)

Providing 24-hour high-quality service

User-friendly online submission system

Fair and swift peer-review system

Efficient typesetting and proofreading procedure

Display of the result of downloads and visits, as well as the number of cited articles Maximum dissemination of your research work

Submit your manuscript at: http://papersubmission.scirp.org/

Or contact jss@scirp.org 